\title{
THE TOLERANCE FOR POTASSIUM IN SEVERE RENAL IN- SUFFICIENCY : A STUDY OF TEN CASES
}

\author{
By NORMAN M. KEITH AND ARNOLD E. OSTERBERG
}

\author{
(From the Division of Medicine, and Section on Clinical Biochemistry, Mayo Clinic, \\ Rochester, Minnesota)
}

(Received for publication July 26, 1946)

The concentration of potassium in the serum of a patient who has developed severe renal insufficiency may be normal, increased, or diminished, and no satisfactory explanation for these widely varied concentrations has been advanced. Naturally the finding of an increased content of potassium in the serum of a nephritic patient suggests caution in the administration of potassium salts. On the other hand there are certain undernourished patients who have nephritis and are suffering from lack of potassium and therefore require an increased intake. It is also recognized that many patients who have renal edema can tolerate a considerable daily dose of potassium salts over a period of months without evidences of toxic effects. It is therefore obvious that there are other factors, in addition to renal retention, which play a role in the distribution of the potassium ion in uremic patients.

Observations of potassium tolerance, both in normal subjects and in patients who had adrenal insufficiency, have been made by $Z$ wemer and Truszkowski (1), Wilder and his co-workers (2), and Jaffe and Byron (3). The effects of a small and of a considerable dose of potassium salts were studied by Greene, Levine and Johnston (4), and by Winkler and his associates (5) in renal disease and by Thomson (6) and Sharpey-Schafer (7) in cardiac disease. The doses employed by Winkler and Sharpey-Schafer were frequently large and sometimes proved impractical and even dangerous. We therefore gave normal subjects and patients who had renal disease a uniform and smaller dose of 5.0 grams of potassium bicarbonate by mouth and were gratified to find that this amount could usually be tolerated and also revealed information as to the individual's tolerance. Our procedures and results in normal subjects have already been reported (8). The present communication deals with the results of the same procedures carried out in 10 patients who had definite renal insufficiency.
Distinct alterations in potassium tolerance were observed in all of the 10 patients and form the basis of this paper.

\section{SELECTION OF PATIENTS}

The chief consideration in the selection of our patients was demonstrable renal insufficiency. Eight of the $10 \mathrm{pa}-$ tients were deliberately chosen because the degree of renal incompetence was marked and we desired particularly to learn the tolerance for potassium of patients who had a minimal amount of functioning renal tissue. The degree of renal insufficiency of these 8 patients was indicated by the increase in the concentrations of urea and creatinine in the blood from 147 to $340 \mathrm{mgm}$. and from 5.6 to $19.2 \mathrm{mgm}$. per $100 \mathrm{ml}$., respectively. The diagnosis in 6 patients was chronic glomerulonephritis; in the 4 remaining, respectively, it was subacute glomerulonephritis, chronic pyelonephritis, bilateral congenital hydronephrosis, and multiple myeloma with chronic diffuse nephritis. Death occurred in 9 of our patients in 2 weeks to 8 months after the test was done. One patient, J. W., with the least degree of renal incompetence, was alive and active when this paper was written, $4 \frac{1}{3}$ years after the test (Table I).

\section{PROCEDURES}

The procedures carried out in the 10 patients started with the early-morning oral administration of 5.0 grams of potassium bicarbonate, which contains approximately 2.0 grams of potassium; during the next 3 hours, a study was made of its effect on the concentration of potassium and urea in the blood, and on serial electrocardiograms. The actual amount of potassium ingested by the 10 patients varied from 24 to $35 \mathrm{mgm}$. per $\mathrm{kgm}$. of body weight. Breakfast was omitted and the patients remained in bed during the period of observation. Control samples of blood were withdrawn from a vein of the arm, and control electrocardiographic tracings were taken before the salt, dissolved in $300 \mathrm{ml}$. of water, was ingested. Subsequently, similar analyses of blood were made and electrocardiograms were taken at approximately 90 and 180 minutes. These were the procedures in 4 cases. In 1 of these, after the patient, H. S., had eaten his lunch, the blood studies and electrocardiograms were subsequently carried out at 8 hours (Tables I to III).

In 6 cases, in addition to the procedure described in the preceding paragraph, studies were made of the clearances of urea and potassium from the blood by the kidneys. 
TABLE I

Clinical data found on initial examination of patients*

\begin{tabular}{|c|c|c|c|c|c|}
\hline $\begin{array}{c}\text { Date } \\
\text { of } \\
\text { admis- } \\
\text { sion }\end{array}$ & $\underset{\text { tient }}{\mathrm{Pa}-}$ & 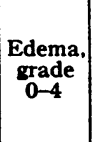 & $\begin{array}{l}\text { Blood } \\
\text { pres- } \\
\text { sure, } \\
\text { range } \\
\text { in 24 } \\
\text { hours }\end{array}$ & $\left|\begin{array}{c}\text { Urine } \\
\text { albu- } \\
\text { min. } \\
\text { grade } \\
0-4\end{array}\right|$ & Diagnosis \\
\hline $10-30-41$ & M.S. & 1 & $\begin{array}{c}m m . H g \\
155-230 \\
95-140\end{array}$ & $3-4$ & Chronic glomerulonephritis \\
\hline $11-28-41$ & P.K. & $1-2$ & $\frac{145-195}{85-130}$ & 4 & $\begin{array}{l}\text { Subacute glomerulonephri- } \\
\text { tis with nephrotic syn- } \\
\text { drome, necropsy }\end{array}$ \\
\hline $11-24-41$ & J.W. & 1 & $\frac{110-140}{60-90}$ & 4 & $\begin{array}{l}\text { Chronic glomerulonephritis } \\
\text { with nephrotic syn- } \\
\text { drome }\end{array}$ \\
\hline $5-17-43$ & M.B. & $\mathbf{0}$ & $\frac{150-200}{110-130}$ & $2-3$ & $\begin{array}{l}\text { Chronic glomerulonephri- } \\
\text { tis, D.A.D. group 2 }\end{array}$ \\
\hline $12-22-41$ & J.B. & 2 & $\frac{130-190}{70-110}$ & $3-4$ & $\begin{array}{l}\text { Chronic glomerulonephritis } \\
\text { with nephrotic syn- } \\
\text { drome, polycythemia } \\
\text { vera }\end{array}$ \\
\hline $5-13-42$ & H.C. & $\mathbf{0}$ & $\frac{110-180}{70-110}$ & $2-3$ & Chronic glomerulonephritis \\
\hline $7-6-42$ & J.R.W. & $\mathbf{0}$ & $\frac{80-105}{40-65}$ & $2 \dagger$ & $\begin{array}{l}\text { Chronic bilateral pyelo- } \\
\text { nephritis }\end{array}$ \\
\hline $9-15-42$ & W.L. $\neq$ & $\mathbf{0}$ & $\frac{180-215}{100-135}$ & 3 & $\begin{array}{l}\text { Chronic glomerulonephri- } \\
\text { tis, D.A.D. group } 4\end{array}$ \\
\hline $9-29-42$ & H.S. 8 & 1 & $\frac{155-190}{100-150}$ & 3 & $\begin{array}{l}\text { Bilateral congenital (?) } \\
\text { hydronephrosis, } \\
\text { necropsy || }\end{array}$ \\
\hline $4-15-43$ & L.G. & $\mathbf{0}$ & $\frac{120-135}{80-85}$ & $3-4 \pi$ & $\begin{array}{l}\text { Multiple myeloma. I } \\
\text { chronic diffuse nephritis }\end{array}$ \\
\hline
\end{tabular}

* Flocculation reactions for syphilis in serum of all 10 patients reported negative.

+ Sediment contained pus, grade 3-4.

¥ Vascular retinitis, edema of disks.

Acute angiospastic retinitis.

If Necropsy elsewhere. Report kindly furnished by Dr. W. L. Ross, Jr., Yakima, Washington.

If Bence-Jones protein present in urine. Smear made from circulating blood has greasy quality and shows occasional myeloid immaturity. Serum protein 8.9 grams, serum albumin 4.0 grams, serum globulin 4.9 grams per $100 \mathrm{ml}$., respectively. Roentgenogram of skull reveals multiple punched-out regions of destruction.

The clearances in 2 periods of approximately $90 \mathrm{~min}$ utes' duration were determined in each of the 6 cases and correlated with the blood estimations and electrocardiographic tracings. Urea clearances were determined to give information as to the amount of renal tissue which was still functioning. The entire study in 4 cases was similar to that performed on normal controls and previously reported.

\section{CLINICAL STUDIES}

Vomiting occurred in only a single case 148 minutes after the patient, $H$. S., had ingested the salt. In this instance the vomitus was recovered; it contained only 0.2 gram of potassium. Three patients experienced mild epigastric discomfort or mild nausea soon after drinking the solution.

In previous studies, when large amounts of potassium salts were ingested by normal subjects, we (9), as well as a previous investigator (10), had noted that in certain cases paresthesias developed in the hands and feet while in other cases they did not develop. These paresthesias occurred when the concentration of potassium in the serum approximated $30 \mathrm{mgm}$. per $100 \mathrm{ml}$. It is interesting that in the present study, with a relatively small dose of 5.0 grams of potassium bicarbonate, paresthesias of the extremities developed in 4 patients, $\mathrm{P}$. K., M. B., H. C. and H. S., when the content of potassium in the serum ranged from 31.1 to 35.8 mgm. per $100 \mathrm{ml}$. These findings suggested that the presence of paresthesias in the 4 patients was indicative of a decreased tolerance for potassium. Support for this viewpoint was the fact that paresthesias did not develop, nor did the serum potassium increase above $21.2 \mathrm{mgm}$. per $100 \mathrm{ml}$. in normal subjects who were given the same dose. In the remaining 6 cases paresthesias did not develop in the extremities; in 2, the maximal serum potassium varied from 19.9 to $27.1 \mathrm{mgm}$. per $100 \mathrm{ml}$. and in 4, it varied from 29.3 to $37.1 \mathrm{mgm}$. per 100 $\mathrm{ml}$. Therefore, this symptom may not develop even when there is a decided increase of the concentration of serum potassium. Patient $\mathrm{H}$. S. (Table II), the only patient to vomit during one of these experiments, was nervous throughout and was suffering from very severe uremia. The slow rise of the concentration of potassium in the serum and the later appearance of changes in the electrocardiogram lead one to surmise that absorption of potassium was at a considerably slower rate in that patient than in the remaining 9.

\section{STUDIES OF THE BLOOD}

We anticipated that the ingestion of 5.0 grams of potassium bicarbonate by our patients would produce changes in the concentration of potassium in the blood serum which would be different from those observed in normal subjects ${ }^{1}$ (Figure 1) (8). In 9 of 10 patients the concentration of potassium in the serum, estimated before the salt was given, was abnormally increased to a range from 21.9 to

1 Nineteen mgm. of potassium per $100 \mathrm{ml}$., a mean normal figure, $=4.9$ m.eq. per 1 . 
TABLE II

Studies of urine and blood and clearance of blood urea and potassium of 10 patients

\begin{tabular}{|c|c|c|c|c|c|c|c|c|c|c|c|c|c|c|c|c|c|}
\hline \multirow{3}{*}{ Date } & \multirow{3}{*}{$\underset{\text { ject }}{\text { Sub- }}$} & \multirow{3}{*}{$\begin{array}{c}\text { Age, } \\
\text { years, } \\
\text { and } \\
\text { sex }\end{array}$} & \multirow{3}{*}{ Weight } & \multirow{3}{*}{ Height } & \multirow{3}{*}{$\begin{array}{l}\text { Body } \\
\text { sur- } \\
\text { face }\end{array}$} & \multirow{3}{*}{$\begin{array}{c}\text { Ex- } \\
\text { peri- } \\
\text { men- } \\
\text { tal } \\
\text { pe- } \\
\text { riods }\end{array}$} & \multicolumn{6}{|c|}{ Urine } & \multicolumn{5}{|c|}{ Blood } \\
\hline & & & & & & & \multirow[b]{2}{*}{$\begin{array}{l}\text { Vol- } \\
\text { ume }\end{array}$} & \multirow[b]{2}{*}{$\begin{array}{c}\text { Min- } \\
\text { ute } \\
\text { vol- } \\
\text { ume } \\
(\mathrm{V})\end{array}$} & \multicolumn{2}{|c|}{ Potassium } & \multicolumn{2}{|c|}{$\begin{array}{c}\text { Urea } \\
.\end{array}$} & \multicolumn{3}{|c|}{ Whole blood } & \multicolumn{2}{|c|}{$\begin{array}{l}\text { Clearances, ml. per } \\
\text { minute }\end{array}$} \\
\hline & & & & & & & & & $\begin{array}{c}\text { Grams } \\
\text { per } \\
100 \\
\text { ml. } \\
\text { (U) }\end{array}$ & Total & $\begin{array}{c}\text { Grams } \\
\text { per } \\
100 \\
\text { ml. } \\
\text { (U) }\end{array}$ & Total & $\begin{array}{c}\text { Hemo- } \\
\text { globin, } \\
\text { grams } \\
\text { per } \\
100 \\
\text { ml. }\end{array}$ & $\begin{array}{c}\text { Urea, } \\
\text { mgm. } \\
\text { per } \\
100 \mathrm{ml} .\end{array}$ & $\begin{array}{c}\text { Creat- } \\
\text { inine, } \\
\text { mgm. } \\
\text { per } \\
100 \\
\text { ml. } \\
\end{array}$ & 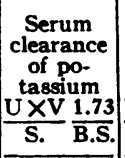 & $\begin{array}{c}\begin{array}{c}\text { Whole } \\
\text { blood } \\
\text { clearance } \\
\text { of urea }\end{array} \\
\frac{\mathrm{U} \times \mathrm{V}}{\mathbf{B}} \frac{1.73}{\mathrm{B.S}}\end{array}$ \\
\hline $11-25-41$ & M.S. & $\underset{F}{20}$ & $\begin{array}{l}\mathrm{kgm} . \\
56.6\end{array}$ & $\begin{array}{l}\mathrm{cm} . \\
163\end{array}$ & $\begin{array}{c}\text { square } \\
\text { meters } \\
1.60\end{array}$ & min- & $m l$. & $m l$. & grams & grams & grams & grams & $\begin{array}{c}\text { grams } \\
13.1\end{array}$ & $\begin{array}{c}m g m . \\
150\end{array}$ & $\begin{array}{c}m g m . \\
5.6\end{array}$ & $m l$. & $m l$. \\
\hline $12-9-41$ & P.K. & $\begin{array}{l}17 \\
\mathbf{M}\end{array}$ & 82.3 & 181 & 2.02 & & & & - & . & - & & 11.7 & 148 & 6.4 & & \\
\hline $12-11-41$ & J.W. & $\begin{array}{l}17 \\
M\end{array}$ & 55.9 & 176 & 1.69 & & & & & & & & 10.8 & 74 & 1.3 & & \\
\hline $10-6-42$ & H.S. & $\begin{array}{l}20 \\
\mathbf{M}\end{array}$ & 74.5 & 181.6 & 1.95 & & & & & & & & 8.1 & 340 & 19.2 & & \\
\hline \multirow[t]{2}{*}{$5-25-43$} & \multirow[t]{2}{*}{ M.B. } & \multirow[t]{2}{*}{$\begin{array}{l}38 \\
\mathbf{M}\end{array}$} & \multirow[t]{2}{*}{68.9} & \multirow[t]{2}{*}{170.2} & \multirow[t]{2}{*}{1.80} & \multirow[t]{2}{*}{$\begin{array}{l}99 \\
89\end{array}$} & $\begin{array}{l}270 \\
180\end{array}$ & \multirow[t]{2}{*}{$\begin{array}{l}2.7 \\
2.0\end{array}$} & \multirow[t]{2}{*}{$\begin{array}{l}0.191 \\
0.258\end{array}$} & $\begin{array}{l}0.516 \\
0.464\end{array}$ & \multirow[t]{2}{*}{$\begin{array}{l}0.508 \\
0.627\end{array}$} & $\begin{array}{l}1.372 \\
1.129 \\
\end{array}$ & \multirow[t]{2}{*}{13.5} & \multirow[t]{2}{*}{$\begin{array}{l}90-90 * \\
90-84 *\end{array}$} & \multirow[t]{2}{*}{2.4} & \multirow[t]{2}{*}{$\begin{array}{l}16 \\
15\end{array}$} & \multirow[t]{2}{*}{$\begin{array}{l}15 \\
14\end{array}$} \\
\hline & & & & & & & 450 & & & 0.980 & & 2.501 & & & & & \\
\hline \multirow[t]{2}{*}{$1-6-42$} & J.B. & $\begin{array}{l}\mathbf{5 8} \\
\mathbf{M}\end{array}$ & 66.0 & 174.5 & 1.80 & $\begin{array}{r}105 \\
87\end{array}$ & $\begin{array}{r}80 \\
110\end{array}$ & $\begin{array}{l}0.76 \\
1.26\end{array}$ & $\begin{array}{l}0.344 \\
0.375\end{array}$ & $\begin{array}{l}0.275 \\
0.413\end{array}$ & $\begin{array}{l}1.240 \\
1.130 \\
\end{array}$ & $\begin{array}{l}0.992 \\
1.243\end{array}$ & 14.2 & $147 \dagger$ & 6.0 & $\begin{array}{r}8 \\
13\end{array}$ & $\begin{array}{l}6 \\
9\end{array}$ \\
\hline & & & & & & & 190 & & & 0.688 & & 2.235 & & & & & \\
\hline $5-22-42$ & H.C. & $\begin{array}{l}\mathbf{3 1} \\
\mathbf{M}\end{array}$ & 78.6 & 158 & 1.80 & $\begin{array}{r}107 \\
95\end{array}$ & $\begin{array}{l}190 \\
130\end{array}$ & $\begin{array}{l}1.8 \\
1.4\end{array}$ & $\begin{array}{l}0.104 \\
0.127\end{array}$ & $\begin{array}{l}0.198 \\
0.165\end{array}$ & $\begin{array}{l}0.629 \\
0.749\end{array}$ & $\begin{array}{l}1.195 \\
0.973\end{array}$ & 8.5 & $\begin{array}{l}242 \dagger \\
242 \ddagger\end{array}$ & 14.4 & $\begin{array}{l}6 \\
6\end{array}$ & $\begin{array}{l}6 \\
4\end{array}$ \\
\hline . & & & & & & & 320 & & & 0.363 & & 2.168 & & & & & \\
\hline $7-13-42$ & J.R.W. & $\begin{array}{l}18 \\
\mathbf{M}\end{array}$ & 55.7 & 160.6 & 1.58 & $\begin{array}{r}110 \\
88\end{array}$ & $\begin{array}{l}155 \\
210\end{array}$ & $\begin{array}{l}1.4 \\
2.4\end{array}$ & $\begin{array}{l}0.084 \\
0.073\end{array}$ & $\begin{array}{l}0.130 \\
0.153\end{array}$ & $\begin{array}{l}0.617 \\
0.574\end{array}$ & $\begin{array}{l}0.956 \\
1.205\end{array}$ & 9.1 & $\begin{array}{l}280-280 * \\
280-282 *\end{array}$ & 15.2 & $\begin{array}{l}5 \\
\mathbf{7}\end{array}$ & $\begin{array}{l}\mathbf{3} \\
\mathbf{5}\end{array}$ \\
\hline & & & & & & & 365 & & & 0.283 & & 2.161 & & & & & \\
\hline $9-23-42$ & W.L. & $\begin{array}{l}32 \\
\mathbf{M}\end{array}$ & 70.0 & 185.4 & 1.94 & $\begin{array}{l}96 \\
83\end{array}$ & $\begin{array}{l}148 \\
110\end{array}$ & $\begin{array}{l}1.5 \\
1.3\end{array}$ & $\begin{array}{l}0.077 \\
0.104\end{array}$ & $\begin{array}{l}0.114 \\
0.114 \\
\end{array}$ & $\begin{array}{l}0.905 \\
0.947\end{array}$ & $\begin{array}{l}1.339 \\
1.042 \\
\end{array}$ & 7.4 & $\begin{array}{l}188-194 * \\
194-192 *\end{array}$ & 10.4 & $\begin{array}{l}6 \\
6\end{array}$ & $\begin{array}{l}6 \\
5\end{array}$ \\
\hline & & & & & & & 258 & & & 0.228 & & 2.381 & & & & & \\
\hline $4-27-43$ & L.G. & $\begin{array}{l}\mathbf{4 0} \\
\mathbf{M}\end{array}$ & 75.7 & 171.5 & 1.89 & $\begin{array}{l}98 \\
90\end{array}$ & $\begin{array}{l}176 \\
138\end{array}$ & $\begin{array}{l}1.8 \\
1.5\end{array}$ & $\begin{array}{l}0.151 \\
0.184\end{array}$ & $\begin{array}{l}0.266 \\
0.255\end{array}$ & \begin{tabular}{|l|}
0.635 \\
0.683
\end{tabular} & $\begin{array}{l}1.118 \\
0.942 \\
\end{array}$ & 8.18 & $\begin{array}{l}200-206^{*} \\
206-204^{*}\end{array}$ & 12.0 & $\begin{array}{l}8 \\
7\end{array}$ & $\begin{array}{l}5 \\
5\end{array}$ \\
\hline & & & & & & & 314 & & & 0.521 & & 2.060 & & & & & \\
\hline
\end{tabular}

* Concentration in whole blood at beginning and end of clearance period.

$\dagger$ Concentration in whole blood at beginning of clearance period.

$\ddagger$ After 180 minutes after ingestion of $\mathrm{KHCO}_{2}$.

Estimation of hemoglobin made after transfusion of $750 \mathrm{ml}$. of blood.

$28.4 \mathrm{mgm}$. per $100 \mathrm{ml}$. (Figure 2). One and a half hours after the ingestion of the potassium bicarbonate the content of potassium in the serum of the 9 patients increased to a range from 23.1 to $37.1 \mathrm{mgm}$. per $100 \mathrm{ml}$. (Figure 2). The greatest increase, from 21.9 to 36.5 , or $14.6 \mathrm{mgm}$., occurred in patient L. G. A similar increase of serum potassium was reported by Greene and his co-workers in a case of chronic nephritis with uremia. With this observation in L. G. and the distinct increase in patient M. S. from 26.7 to 37.1 $\mathrm{mgm}$., we realized that even 5.0 grams of potassium bicarbonate might produce serious toxic effects, especially on the heart. It was rather surprising that the serum potassium in patient $\mathrm{J}$. R. W., who had very serious renal disease, increased only to $27.1 \mathrm{mgm}$. In 3 hours (Figure 2) there was a decrease in the concentration of the potassium of the serum in 7 patients to values ranging from 24.0 to $35.4 \mathrm{mgm}$., but in 2 patients, J. B. and H. S., it increased 2.1 and $8.0 \mathrm{mgm}$., respectively. J. B. had taken a considerable amount of potassium nitrate as a diuretic previous to the tolerance test. The increase in patient $\mathrm{H}$. S. from $23.1 \mathrm{mgm}$. at $1 \frac{1}{2}$ hours to $31.1 \mathrm{mgm}$. at 3 hours was marked. This late increase in the content of 


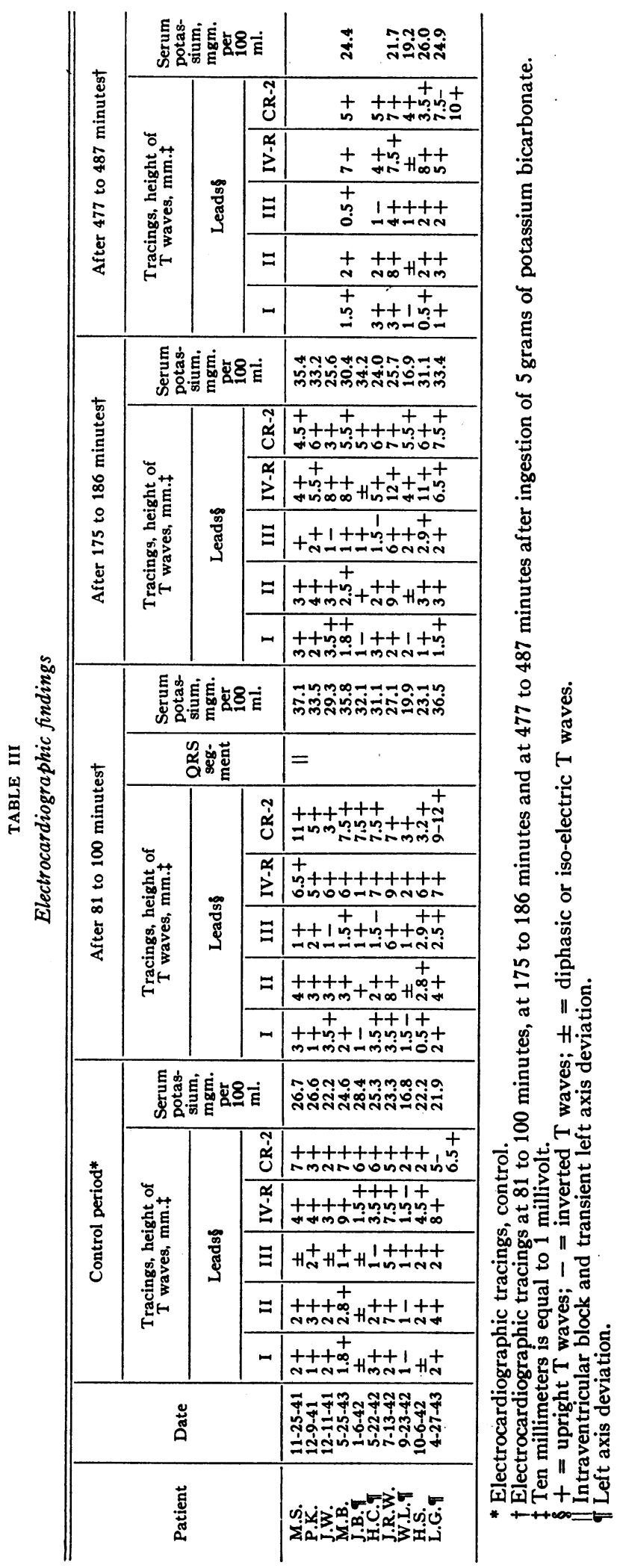


potassium in the serum of patient $\mathrm{H}$. S. would appear to be due to a slow absorption of potassium from the intestinal tract. In 4 of the 9 patients, the concentration of potassium was estimated after 8 hours and it had decreased to 21.7 to $26.0 \mathrm{mgm}$., but in 3 of the 4 patients it was at a higher level than that observed in the original control serum. These results in 9 patients indicated a varied and unmistakably abnormal response to the ingestion of a relatively small amount of a potassium salt. The type of response was that of a decreased tolerance for potassium (Figures 1 and 2).

The findings, however, in patient W. L. were distinctly different from those in the 9 other patients. In fact, the alterations in the concentration of potassium in the serum (Figure 2) could not be distinguished from that obtained in a normal subject (Figure 1) after the ingestion of 5.0 grams of potassium bicarbonate. This response in a patient with such a severe degree of renal damage, the latter indicated by a blood urea clearance of $6 \mathrm{ml}$., surely informs us that the curve of serum potassium after the ingestion of a relatively small dose of a potassium salt may not reveal an altered potassium tolerance. The possibility of decreased absorption of the potassium salt from the intestine of this patient naturally must be considered. However, there is good evidence that intestinal absorption was satisfactory. This point will be discussed later.

\section{STUDIES OF THE URINE AND BLOOD CLEARANCES OF UREA AND POTASSIUM}

During the 2 clearance periods of approximately $11 / 2$ hours, 3 hours in all, after taking 5.0 grams of potassium bicarbonate by mouth, the mean volume of urine in the 6 patients whose urine was studied (Table II) was definitely less than that observed in normal subjects under the same experimental conditions. In fact the mean volume of urine excreted in 3 hours by 5 normal subjects was $497 \mathrm{ml}$. as compared with $316 \mathrm{ml}$. excreted by 6 patients. The concentrations of urea and potassium in the urine had a smaller range and were often lower than in the normal subjects. The mean of the total amounts of urea excreted was diminished. Also, the total amount of potassium eliminated was decreased and in patient W.L. was only 0.23 gram in 3 hours. If this amount of potassium was evenly excreted throughout the day it would total 1.8 grams in 24 hours, which approximates that excreted by a normal starving

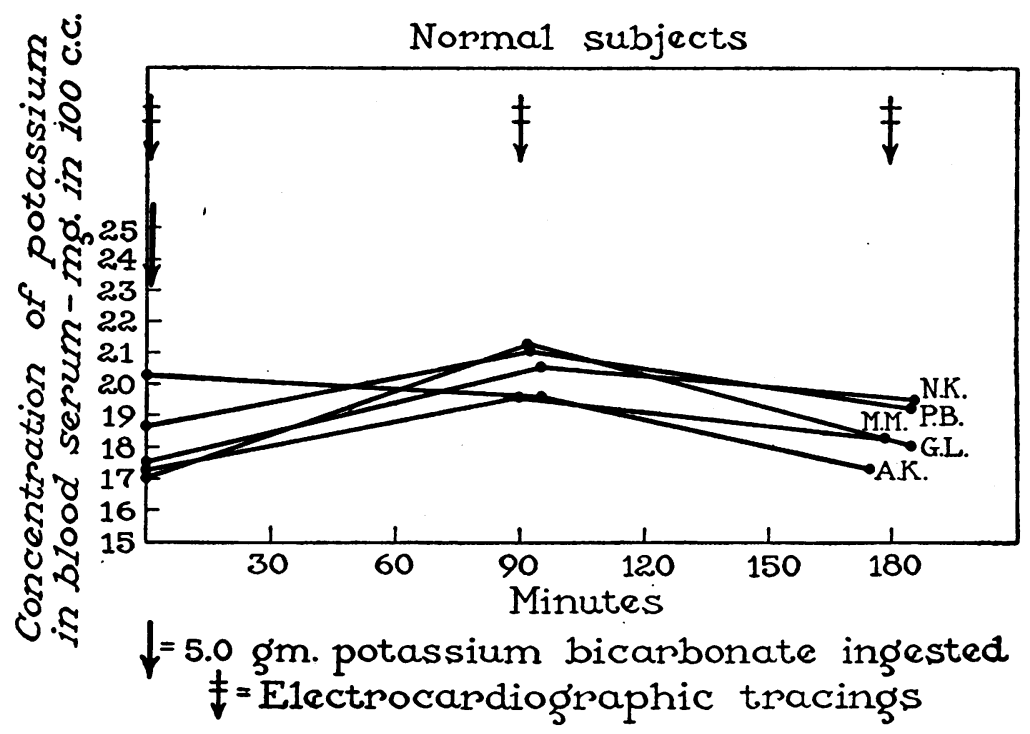

Fig. 1. Five Normal Subjects. The Concentration of Potassium in the Blood Serum Bepore and at $11 / 2$ and 3 Hours After the Ingestion of 5.0 Grams of Potassium Bicarbonate

Details of these studies reported in Proceedings of the Staff Meetings of the Mayo Clinic (8). 


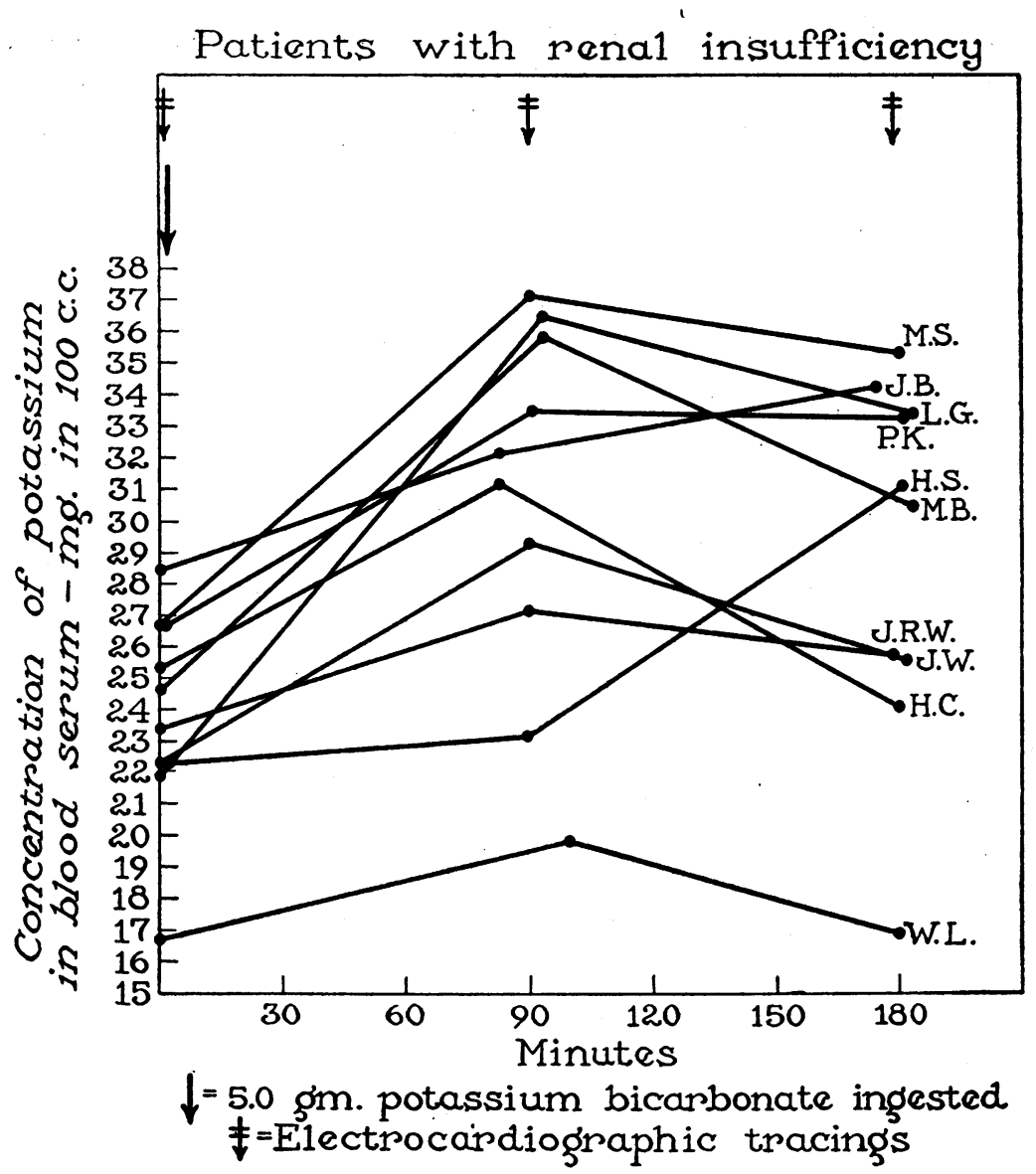

Fig. 2. Ten Patients with Renal Insufficiency. The Concentration of Potassium in the Blood Serum Before and at $1 \frac{1}{2}$ and 3 Hours After the Ingestion of 5.0 Grams of Potassium Bicarbonate

In 9 patients the serum potassium is distinctly increased over that observed in normal subjects. Compare with Figure 1. In 3 patients, M. S., M. B., and L. G., the serum potassium at $1 \frac{1}{2}$ hours increased to a potential toxic concentration. The curve of patient W. L. is similar to that of normal subjects.

subject. $^{2}$ Therefore, patient W. L. was unable in 3 hours to eliminate any of the extra potassium ingested. A similar calculation for 5 other patients revealed an excretion in 3 hours of 4 to 39 per cent of the extra potassium ingested. This is in distinct contrast to a range from 49 to 100 per cent in our studies on normal subjects.

The clearances of urea were greatly decreased to a range from 3 to $15 \mathrm{ml}$. (Table II). The clearances of potassium, ranging from 5 to $16 \mathrm{ml}$., however, were similar to those observed in normal

\footnotetext{
2 In Benedict's study (11), the starving subject on the first day of a prolonged fast excreted 1.63 grams of potassium in the urine.
}

subjects and in some patients who had renal insufficiency, when both subjects and patients were fasting and ingesting water only. It is clear, however, that the clearances of potassium, ranging from 5 to $16 \mathrm{ml}$., for our patients were distinctly less than those obtained, ranging from 29 to $67 \mathrm{ml}$., for normal subjects who had taken 5.0 grams of potassium bicarbonate. These facts indicate that in our patients there was a diminished and slower response of the kidneys to the stimulus of the potassium salt than in the normal subject. The kidneys of these patients were capable only of eliminating a dilute urine but were enabled by continuous excretion of potassium during the entire 24 
hours to prevent its excessive retention in the blood.

The variability of the increases in the concentration of potassium in the serum of 6 patients contrasted markedly with the uniformity of the diminution of urinary excretion and clearances of potassium. The serum concentration, 11/2 hours after ingesting the salt, varied from 19.9 to 36.5 mgm. or an increase of 5 to 92 per cent from a normal mean concentration of $19.0 \mathrm{mgm}$. in $100 \mathrm{ml}$. The mean reduction in the renal excretion of potassium in the 6 patients compared to that in normal subjects amounted to 1.09 grams or 32 per cent.

The decreased excretion and clearance of potassium in patient W. L. is unusually interesting, for, as stated in a previous section, the curve of the concentration of potassium in the blood serum (Figure 2) was identical with that observed in normal subjects (Figure 1) and one would therefore infer that this patient had a normal tolerance for potassium. However, the greatly reduced renal excretion of potassium (Table II) signified a decreased tolerance for potassium on the part of a single organ, the kidney. The results in patient W. L. also emphasized the important fact that there must be several organs that play a role in the internal regulation of potassium.

\section{STUDIES OF THE ELECTROCARDIOGRAM 3}

There were 2 chief reasons for including serial electrocardiographic observations in the study of our 10 patients. The first was to ascertain whether 5.0 grams of potassium bicarbonate, when given to these patients, would cause alterations in the electrocardiogram similar to those observed in normal subjects. The second reason was to determine whether this relatively moderate dose of potassium bicarbonate would lead in patients to an excessive increase in the concentration of potassium in the serum and thus produce toxic effects on the heart. In each of the 10 patients serial electrocardiograms revealed some alterations in the $T$ waves of the electrocardiogram ( $T a b l e$ III). The alterations were often, though not invariably similar to those observed in normal subjects. Thus 5 normal subjects and 10 patients on whom this test was performed have revealed

\footnotetext{
3 The authors are indebted to Dr. H. B. Burchell for this detailed interpretation of the electrocardiograms.
}

changes in the electrocardiogram which we think are due to a rapid increase of potassium in the myocardium. As was to be expected, changes observed in the patients were more varied than in the normal subjects; as a rule they persisted for a longer period and were sometimes observed for 8 hours after the taking of the salt. The changes due to potassium were sometimes more difficult to evaluate in patients than in the normal subject because a number of the control electrocardiograms of the patients were abnormal. For example, several patients had previously had severe hypertension and a tracing characteristic of left ventricular strain (Table III). Figures $3 \mathrm{~A}$ and $\mathrm{B}$ show serial electrocardiograms with characteristic and varied alterations in 2 of our patients (J.R. W. and M. S.).

The electrocardiographic findings for patient H. S. (Table III) confirmed our previous clinical conception that potassium was more slowly absorbed from his intestine than in the 9 other patients. The curve of serum potassium slowly rose from 22.2 to $23.1 \mathrm{mgm}$. in $1 \frac{1}{2}$ hours, and to its peak, $31.1 \mathrm{mgm}$., in 3 hours and fell to $26.0 \mathrm{mgm}$. only after 8 hours. The concomitant changes in the electrocardiogram at $1 \frac{1}{2}$ hours revealed increased $T$ waves, but at 3 hours these alterations in the $\mathrm{T}$ waves were much greater and appeared to be at their peak. Characteristic changes of the $T$ waves, though less than at 3 hours, were present at 8 hours.

The electrocardiographic changes revealed in patient W. L. (Table III) at $1 \frac{1}{2}$ and 3 hours, though somewhat atypical, are of interest. It was previously pointed out that in this patient the concentration of potassium in the serum increased only $3.1 \mathrm{mgm}$. at $1 \frac{1}{2}$ hours, an increase similar to that found in normal subjects. Therefore we believe we have evidence in this patient that at least some of the potassium salt was rapidly absorbed from the intestine and produced concurrent effects in the blood serum and in the myocardium that are comparable with the response of the normal subject. The abnormally decreased renal excretion of potassium was the only evidence of a disturbed tolerance for this ion. The entire response in this patient could be explained by a decreased absorption of potassium from the intestinal tract. However, the evidence given earlier in this paragraph 
and the fact that some uremic patients have an abnormally low concentration of potassium in the serum and hence a low concentration in other tissues strongly support the viewpoint that normal absorption occurred and that the extra potassium entered tissues low in potassium content.

We have reliable evidence from the electrocardiographic and blood studies of patient M. S. (Fig- ure $3 \mathrm{~B}$ ) that even the ingestion of 5.0 grams of potassium bicarbonate will produce toxic effects on the heart. In $1 \frac{1}{2}$ hours the content of potassium in the blood serum rose from 26.7 to 37.1 mgm. (Figure 2), an increase of $10.4 \mathrm{mgm}$., and the electrocardiographic tracings revealed early intraventricular block (Table III, Figure 3B). Previously we $(12,13)$, as well as other investiga-

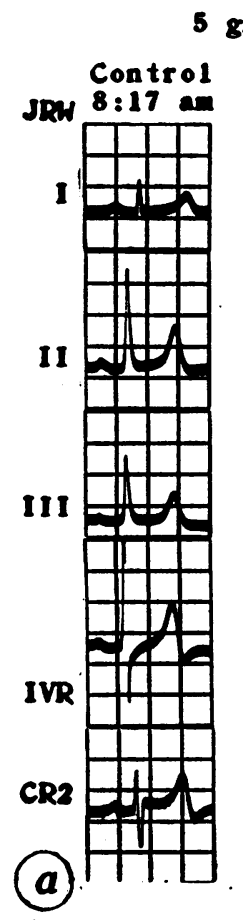

Serum $K=g$. in 100 c.c. 23.3
5 8m. $\mathrm{KHCO}_{3}$ at $8: 26 \mathrm{AH}$

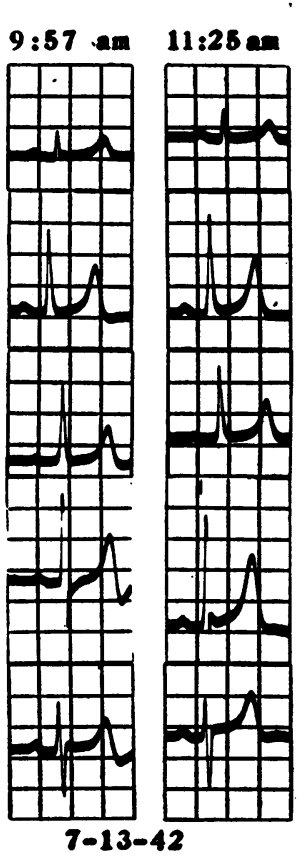

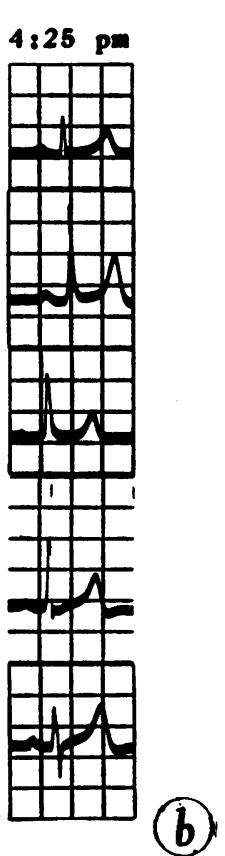

(b)

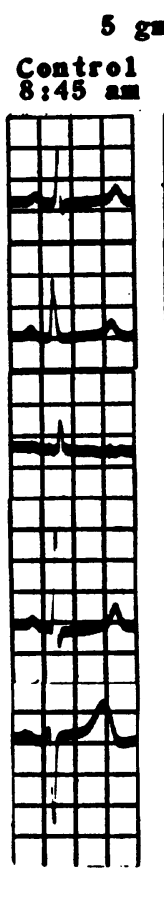

58
. $\mathrm{KHCO}_{3}$ at $8.31 \mathrm{NH}$

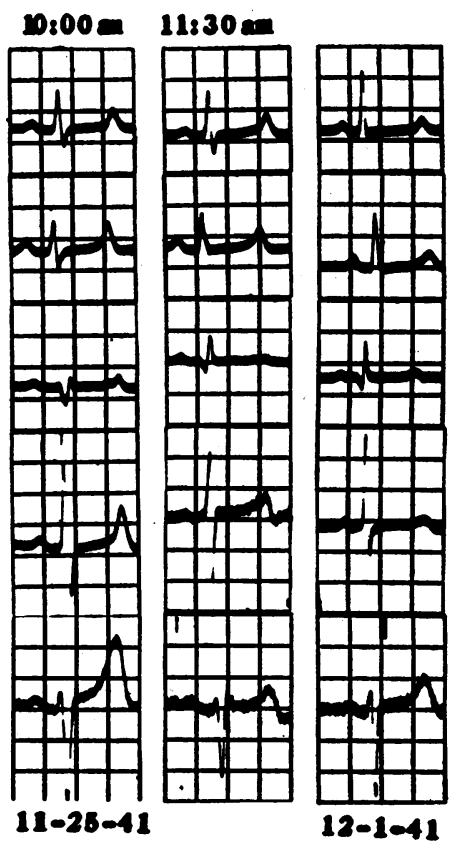

Fig. 3A. Patient J. R. W. Serial Electrocardiograms Showing the Effect of Increased Serum Potassium Levels

The patient did not reveal any abnormal cardiovascular findings. The first column, recorded shortly before administration of potassium, is normal. Following the ingestion of the potassium salt, the records show increases of the voltage of the T wave ( $2 \mathrm{~mm}$. in lead II, $4 \mathrm{~mm}$. in lead IV-R). It is to be noted that while the potassium level has fallen $1.4 \mathrm{mgm}$. between 9:57 and 11:25 a.m., the $\mathrm{T}$ waves are at their highest at the latter time. In IV-R there are loss of the late negativity and a slight elevation of the R-T interval. The QRS complexes and the various time intervals do not show any significant change.

B. Patient M. S. Serial Electrocardiograms Showing the Effect of Increased Levels of PoTASSIUM in THE SERUM

The control tracing is an essentially normal electrocardiogram. With the increase of serum potassium level there is a concomitant increase in the height of the $T$ wave and in the length of the QRS interval (from 0.07 to 0.09 second). The QRS has become more biphasic and suggests the beginning of the intraventricular conduction defect which is so characteristic of the tracing in patients having potassium concentrations approaching the lethal level. Such a tracing has not been observed previously with such a small dose of a potassium salt. Attention is drawn to the characteristic sharply peaked, narrow-base configuration of the $T$ waves as seen in leads II and IV$\mathrm{R}$ of the second column. The $\mathrm{Q}-\mathrm{T}$ intervals are respectively $0.48,0.48,0.44$, and 0.44 second and the corresponding $\mathrm{R}-\mathrm{R}$ times are $1.05,0.90,1.10$, and 1.15 seconds respectively. On November 26 the serum calcium was 8.4 mgm. per $100 \mathrm{ml}$. 
tors (14), have reported a similar degree of hyperpotassemia and electrocardiographic -findings of intraventricular block among patients suffering from severe uremia and not receiving therapeutic doses of potassium salts. These patients died shortly afterward because of the toxic effect of the potassium on the heart. Fortunately, in this patient at the end of 3 hours the evidence of intraventricular block had almost disappeared although the concentration of potassium in the serum was still high, $35.4 \mathrm{mgm}$. Several days later, electrocardiograms were taken and proved to be identical with those observed before the potassium salt was ingested. Sharpey-Schafer in 1943 (7) reported the temporary induction of intraventricular

- block in a patient who had myocardial degeneration and had ingested a much larger dose, 15 grams of potassium salts. Our experience with patient M. S. affords objective evidence that in chronic nephritis there may be a marked decrease of the tolerance for potassium and hence the administration of potassium salts may be a dangerous procedure. On the other hand, it is significant that in the remaining 9 patients, some of whom had very severe renal insufficiency, the electrocardiogram did not reveal definite intraventricular dysfunction:

\section{COMMENT}

In 4 cases paresthesias developed in the extremities, a fact which we think is clinical evidence of a lowered potassium tolerance, because these symptoms were observed previously only in subjects to whom much larger doses of potassium had been administered. In all of our 10 patients the excretion of potassium by the kidney was decreased, and in 9 there was an abnormal rise of the curve of serum potassium. Both results indicated a definite decrease of tolerance.

The concentration of potassium in the serum rose to potentially dangerous levels in 3 patients, but only in a single instance did it produce a demonstrable toxic effect on the cardiac muscle. In the 3 patients, the extra potassium ingested was presumably distributed chiefly in the extracellular fluid of the body. Calculation of the distribution of potassium in 1 of these, patient L. G., was as follows: His body weight amounted to $75.7 \mathrm{kgm}$. If 20 per cent of the body weight may be con- sidered to represent the volume of extracellular fluid, in this subject it would amount to, therefore, $15,000 \mathrm{ml}$. If then 2.0 grams of potassium, less that excreted in the urine, is dissolved in 15,000 $\mathrm{ml}$. of fluid, the estimated increase in the concentration of potassium would be $12 \mathrm{mgm}$. per 100 $\mathrm{ml} .{ }^{4}$ The observed increase in the patient's serum was $14.6 \mathrm{mgm}$. per $100 \mathrm{ml}$., which is in close agreement with the calculated value.

In 7 patients the potassium ingested was presumably distributed, in varying proportions, between the extracellular and the intracellular fluid. However, in a single patient a large proportion apparently entered rapidly into the intracellular fluid. This result would lead one to believe that the stores of potassium in the cells of this patient were depleted, despite the presence of severe renal insufficiency. Our results, therefore, indicate a marked variation in the distribution of potassium between the 2 reservoirs of body fluid.

The small increase in the serum curve of patient W. L. also suggests the possibility that in certain patients who have uremia there may be an actual increase of tolerance for potassium. In this connection several observers have recorded concentrations of serum potassium distinctly below the normal range in patients who have renal disease (12). We reported a content of $12.8 \mathrm{mgm}$. per $100 \mathrm{ml}$. of serum in 1 such patient (15) and Brown, Currens and Marchand (16) reported a concentration of $7.8 \mathrm{mgm}$. in the case they reported.

In the present study we have demonstrated the occurrence of a decreased tolerance for potassium. This is in agreement with the findings in the blood serum in 2 cases of renal insufficiency published by Greene and his co-workers. Considerable evidence also has been advanced for the presence of both a normal and an increased tolerance. Further research is necessary to prove the occurrence of these latter conditions. Studies of potassium tolerance are also needed in the states of inanition or semistarvation, which develop rather frequently among patients suffering from chronic uremia.

In a previous paper (17) we recommended caution in administering potassium salts to a nephritic patient who has edema and in whom the concentration of urea in the blood is $100 \mathrm{mgm}$. or

$$
\frac{2,000 \mathrm{mgm} .-266 \mathrm{mgm} .}{15,000}=12 \mathrm{mgm} . \text { per } 100 \mathrm{ml} \text {. }
$$


more per $100 \mathrm{ml}$. In 9 cases, in our present series, in which the tolerance for potassium was reduced, the urea content of the blood varied from 90 to 340 mgm. per $100 \mathrm{ml}$. We still rely on this chemical observation as a precautionary measure. Therefore, it is suggested that a potassium tolerance test be carried out if a patient has a blood urea of $100 \mathrm{mgm}$. per $100 \mathrm{ml}$. and the results should provide evidence as to whether or not a potassium salt could be safely administered. Winkler, Hoff, and Smith (5) have emphasized the point that oral administration of potassium salts to patients who have nephritic edema is a reasonably safe procedure and our results support their contention, especially when there is an adequate renal excretion of the metabolites, urea, sulfate, and creatinine. Fortunately the majority of patients who have nephritic edema will reveal a concentration of urea in the blood which is much less than 100 mgm. per $100 \mathrm{ml}$.

\section{SUM MARY}

A diminished tolerance for potassium has been demonstrated in a series of uremic patients. Other results of this study suggest the presence of a normal tolerance and even an increased tolerance for potassium in certain phases of uremia but further research is necessary to prove or disprove their actual occurrence.

\section{BIBLIOGRAPHY}

1. Zwemer, R. L., and Truszkowski, Richard, Factors affecting human potassium tolerance. Proc. Soc. Exper. Biol. \& Med., 1936, 35, 424.

2. Wilder, R. M., Kendall, E. C., Snell, A. N., Kepler, E. J., Rynearson, E. H., and Adams, Mildred, Intake of potassium, an important consideration in Addison's disease: a metabolic study. Arch. Int. Med., 1937, 59, 367.

3. Jaffe, I., and Byron, C., Potassium tolerance test as aid in diagnosis of adrenal insufficiency. J. Clin. Endocrinol., 1942, 2, 339.

4. Greene, J. A., Levine, Harry, and Johnston, G. W., Is the potassium tolerance curve of value in the diagnosis of adrenal cortical insufficiency in man? Endocrinology, 1940, 27, 375.

5. Winkler, A. W., Hoff, H. E., and Smith, P. K., The toxicity of orally administered potassium salts in renal insufficiency. J. Clin. Invest., 1941, 20, 119.

6. Thomson, W. A. R., The effect of potassium on the heart in man. Brit. Heart J., 1939, 1, 269.

7. Sharpey-Schafer, E. P., Potassium effects on $T$ wave inversion in myocardial infarction and preponderance of a ventricle. Brit. Heart J., 1943, 5, 80.

8. Keith, N. M., and Osterberg, A. E., The human tolerance for potassium. Proc. Staff Meet., Mayo Clin., 21 : 385-392 (Oct. 2) 1946.

9. Keith, N. M., Osterberg, A. E., and Burchell, H. B., Some effects of potassium salts in man. Ann. Int. Med., 1942, 16, 879.

10. Arden, Felix, Experimental observations upon thirst and on potassium overdosage. Australian J. Exper. Biol. \& M. Sc., 1934, 12, 121.

11. Benedict, F. G., A study of prolonged fasting. Washington, D. C., Carnegie Inst., 1915, p. 203.

12. Keith, N. M., King, H. E., and Osterberg, A. E., Serum concentration and renal clearance of potassium in severe renal insufficiency in man. Arch. Int. Med., 1943, 71, 675.

13. Keith, N. M., Burchell, H. B., and Baggenstoss, A. H., Electrocardiographic changes in uremia associated with a high concentration of serum potassium; report of three cases. Am. Heart J., 1944, 27, 817.

14. Marchand, J. F., and Finch, C. A., Fatal spontaneous potassium intoxication in patients with uremia. Arch. Int. Med., 1944, 73, 384.

15. Rosenberg, E. F., Keith, N. M., and Wagener, H. P., Diffuse arterial disease with hypertension; two unusual cases of contrasting types. Arch. Int. Med., 1938, 62, 461.

16. Brown, M. R., Currens, J. H., and Marchand, J. F., Muscular paralysis and electrocardiographic abnormalities resulting from potassium loss in chronic nephritis. J. A. M. A., 1944, 124, 545.

17. Keith, N. M., and Binger, M. W., Diuretic action of potassium salts. J. A. M. A., 1935, 105, 1584.

METHODS OF CHEMICAL ANALYSIS EMPLOYED IN THE PRESENT STUDY

Whole blood

Hemoglobin-Sanford, A. H., Sheard, Charles, and Osterberg, A. E., The photelometer and its use in the clinical laboratory. Am. J. Clin. Path., 1933, 3, 405.

Urea-Van Slyke, D. D., and Cullen, G. E., A permanent preparation of urease, and its use in the determination of urea. J. Biol. Chem., 1914, 19, 211.

Creatinine-Folin, Otto, Laboratory manual of biologic chemistry with supplement. Ed. 3, New York, D. Appleton \& Company, 1922, pp. 149, 245 and 247.

\section{Serum}

Potassium-Kramer, Benjamin, and Tisdall, F. F., A clinical method for the quantitative determination of potassium in small amounts of serum. J. Biol. Chem., $1921,46,339$. This method in our hands has checked with gravimetric procedures. The precipitation by sodium cobaltinitrite was allowed to proceed for $\mathbf{4 5}$ minutes at icebox temperature in order to obtain a good granular precipitate. If this and other steps are rigorously adhered to, the method is satisfactory. 
Calcium-Clark, E. P., and Collip, J. B., A study of the Tisdall method for the determination of blood serum calcium with a suggested modification. J. Biol. Chem., $1925,63,461$.

Total proteins-Macro-Kjeldahl technic of estimation of total nitrogen and total protein, calculated after subtracting nonprotein nitrogen as estimated by the micro-Kjeldahl method.

Albumin and globulin fractions-Howe, P. E., The de- termination of proteins in blood; a micro method. J. Biol. Chem., 1921, 49, 109. Kingsley, G. R., A rapid method for the separation of serum albumin and globulin. J. Biol. Chem., 1940, 133, 731.

$$
\text { Urine }
$$

Urea-Same method as for whole blood.

Potassium-Same method as for estimation in serum except that urine is ashed before precipitation. 